\title{
Remote sensing of size structure of phytoplankton communities using optical properties of the Chukchi and Bering Sea shelf region
}

\author{
A. Fujiwara ${ }^{1}$, T. Hirawake ${ }^{2}$, K. Suzuki ${ }^{3}$, and S.-I. Saitoh ${ }^{2}$ \\ ${ }^{1}$ Graduate School of Fisheries Sciences, Hokkaido University, 3-1-1 Minato-cho, Hakodate, Hokkaido 041-8611, Japan \\ ${ }^{2}$ Faculty of Fisheries Sciences, Hokkaido University, 3-1-1 Minato-cho, Hakodate, Hokkaido 041-8611, Japan \\ ${ }^{3}$ Faculty of Environmental Earth Science, Hokkaido Univ., North 10 West 5, Kita-ku, Sapporo, Hokkaido 060-0810, Japan
}

Received: 22 April 2011 - Published in Biogeosciences Discuss.: 23 May 2011

Revised: 18 October 2011 - Accepted: 3 November 2011 - Published: 8 December 2011

\begin{abstract}
Recent ocean warming and subsequent sea ice decline resulting from climate change could affect the northward shift of the ecosystem structure in the Chukchi Sea and Bering Sea shelf region (Grebmeier et al., 2006b). The size structure of phytoplankton communities provides an index of trophic levels that is crucial to understanding the mechanisms underlying such ecosystem changes and their implications for the future. This study proposes a new ocean color algorithm for deriving this characteristic by using the region's optical properties. The size derivation model (SDM) estimates the phytoplankton size index $F_{\mathrm{L}}$ on the basis of sizefractionated chlorophyll- $a$ (chl- $a$ ) using the light absorption coefficient of phytoplankton, $a_{\mathrm{ph}}(\lambda)$, and the backscattering coefficient of suspended particles including algae, $b_{\mathrm{bp}}(\lambda) . F_{\mathrm{L}}$ was defined as the ratio of algal biomass attributed to cells larger than $5 \mu \mathrm{m}$ to the total. It was expressed by a multiple regression model using the $a_{\mathrm{ph}}(\lambda)$ ratio, $a_{\mathrm{ph}}(488) / a_{\mathrm{ph}}(555)$, which varies with phytoplankton pigment composition, and the spectral slope of $b_{\mathrm{bp}}(\lambda), \gamma$, which is an index of the mean suspended particle size. A validation study demonstrated that $69 \%$ of unknown data are correctly derived within $F_{\mathrm{L}}$ range of $\pm 20 \%$. The spatial distributions of $F_{\mathrm{L}}$ for the cold August of 2006 and the warm August of 2007 were compared to examine application of the SDM to satellite remote sensing. The results suggested that phytoplankton size was responsive to changes in sea surface temperature. Further analysis of satellite-derived $F_{\mathrm{L}}$ values and other environmental factors can advance our understanding of ecosystem structure changes in the shelf region of the Chukchi and Bering Seas.
\end{abstract}

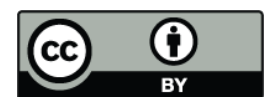

Correspondence to: A. Fujiwara (amane@salmon.fish.hokudai.ac.jp)

\section{Introduction}

The Chukchi Sea, located at the western edge of the Arctic Ocean, and the Bering Sea, located at the northern edge of the Pacific Ocean, are connected by the Bering Strait. The continental shelf spreads north and south of the Bering Strait for $2000 \mathrm{~km}$, and the water depths are shallower than $50 \mathrm{~m}$ in most of the region. Three types of water masses flow through the region: Alaskan Coastal Water (ACW), Anadyr Water (AW), and Bering Shelf Water (BSW). ACW has a high temperature and low salinity due to fresh water input; it passes along the western coast of Alaska and flows out to the Beaufort Sea (Coachman et al., 1975). AW, which flows along the eastern coast of Siberia, has a low temperature and high salinity, and supplies large amounts of nutrients to the Bering Sea and Bering Strait (Coachman et al., 1975). BSW flows between AW and ACW. Its water density is very similar to that of AW, so they become well mixed when they pass through the Bering Strait (Grebmeier et al., 1988). This mixed water, called Bering Shelf-Anadyr Water (BSAW) (Grebmeier et al., 1988) supplies nutrient-rich water to the southern Chukchi Sea.

The shelf region influenced by BSAW is known as one of the most highly productive regions in the world's oceans. The maximum primary production reaches $840 \mathrm{gC} \mathrm{m}^{-2} \mathrm{yr}^{-1}$ (Springer and McRoy, 1993). Organic carbon produced at the surface and subsurface layers by phytoplankton is exported efficiently to the bottom because of the shallow depth and the low grazing impact of zooplankton (Grebmeier et al., 1988; Feder et al., 2005), and supports a high benthic biomass in the region. Consequently, large benthic feeders at high trophic levels such as gray whales (Eschrichtius robustus) and walrus (Odobenus rosmarus divergens) also congregate here (Feder et al., 2005). This unique ecosystem

Published by Copernicus Publications on behalf of the European Geosciences Union. 
structure with a significantly short food chain forms because of the tightly linked energy transport between phytoplankton and benthos (Grebmeier et al., 2006b).

Recently, remotely sensed microwave observations by satellite have indicated that the sea ice area in the Arctic Ocean is declining annually (e.g. Comiso et al., 2008; Parkinson and Cavalieri, 2008). This is especially significant in September when the largest open water area occurs (e.g. Comiso, 2002; Shimada et al., 2006). Shimada et al. (2006) noted that a recent reduction in sea ice cover is due to increasing heat flux from Pacific summer water. Woodgate et al. (2006) also showed that the increase in heat flux in 2001-2004 is attributable to a volume flux increase of Pacific water, corresponding to $\sim 640000 \mathrm{~km}^{2}$ of 1-m-thick ice melting in these four years. Shimada et al. (2006) suggested that the reduction in sea ice causes less ice-productive conditions in the Western Arctic and forms a positive feedback mechanism toward further sea ice reduction.

Various effects of reduced sea ice and increased temperature on the marine ecosystem have been reported. Arrigo et al. (2008) and Pabi et al. (2008), for example, suggested that annual primary production in the Arctic Ocean has been increasing owing to increases in the algal growth season and habitat area resulting from diminishing sea ice area. Grebmeier et al. (2006a) note that the tightly linked phytoplankton-benthos ecosystem structure (pelagic-benthic type) is forced to shift northward because of ocean warming. Consequently, the ecosystem structure switches from shortchained pelagic-benthic type to a pelagic-pelagic (algaezooplankton) type having more trophic levels. Although the ecosystem structure in the study region is likely to be in a dramatic transitional phase right now, it is still unknown how the distribution of phytoplankton community structure varies owing to environmental change. Because phytoplankton is the basis of the ecosystem, its community structure (size or taxonomic composition) can be an important factor for assessing the response of the ecosystem to environmental change. Thus, it is necessary to clarify the spatial and temporal variability of the phytoplankton distribution in the shelf region.

The first satellite ocean color sensor, the Coastal Zone Color Scanner (CZCS), was launched in 1978 and provided high spatiotemporal data until 1986. Sensors such as the Seaviewing Wide Field-of-view Sensor (SeaWiFS) and Moderate Resolution Spectroradiometer (MODIS) have also provided higher-quality ocean color data. The most successful result of satellite observations has been the provision estimates of chlorophyll- $a$ (chl- $a$ ) concentration, which is an index of phytoplankton biomass, over wide spatial and temporal scales. Seasonal phytoplankton cycles have been clarified at not only regional but also global scales (Yoder and Kennelly, 2006). Chl- $a$ is still the main index provided by ocean color satellites for improving oceanographic knowledge. Recently, several attempts have also been made to develop methods that use ocean color data to estimate the dom- inant distribution of Phytoplankton functional types (PFTs), including phytoplankton size classes at large spatial scales (e.g. Sathyendranath et al., 2004; Alvain et al., 2005) or their fractional contribution to total biomass (Uitz et al., 2006; Ciotti and Bricaud, 2006; Bracher et al., 2009; Kostadinov et al., 2009; Mouw and Yoder, 2010; Brewin et al., 2010; Devred et al., 2011; Hirata et al., 2011). It has recently been established that different phytoplankton groups make different contributions to large-scale-biogeochemical cycles in the ocean; these groups are called PFTs. For example, there are nitrogen fixing groups (Zehr and Carpenter, 2000) and groups that produce dimethylsulfide (DMS) (a precursor of cloud condensation nuclei) (Turner et al., 1988); even the carbon-fixating efficiency varies among groups (Lochte et al., 1993). Since it is an important factor in determining the number of trophic levels of a regional ecosystem (Lalli and Parsons, 1995), dominant cell size of phytoplankton is also described as a PFT.

The use of the inherent optical properties (IOPs) (absorption and backscattering) of seawater is the principle method of estimating PFT composition optically because some PFT's dominance can change IOPs of the water. The IOPs influenced by PFT composition affect the property of waterleaving radiance $L_{\mathrm{w}}$ (see Table 1 for symbols), which can be observed directly by satellite sensors. Several studies (e.g. Sathyendranath et al., 2004; Alvain et al., 2005; Mouw and Yoder, 2010) have suggested that quantifying the relationship between PFT composition and IOPs allows us to estimate their distribution, especially in Case 1 waters where phytoplankton particles and their related materials are major contributor of optical properties in the water (Morel and Prieur, 1977). Fishwick et al. (2006), for instance, showed a significant difference in the spectral ratio of the absorption coefficient $a_{\mathrm{ph}}(\lambda)$, i.e. the ratio of $a_{\mathrm{ph}}(676)$ to $a_{\mathrm{ph}}(440)$ $\left(a_{\mathrm{ph}}[676] / a_{\mathrm{ph}}[440]\right)$, among dominant phytoplankton groups, which coincides with the ratio of the accessory pigments to chl- $a$ or maximum photosynthetic quantum efficiency. They suggested that the ratio of $a_{\mathrm{ph}}(\lambda)$ at red light to that at blue light should be an indicator for determining the dominance of PFTs, at least for the Benguela ecosystem. On the other hand, the spectral shape of the particle backscattering coefficient $b_{\mathrm{bp}}(\lambda)$ is known to vary with the mean size of suspended particles in the water (e.g. Bricaud and Morel, 1986; Stramski et al., 2001; Vaillancourt et al., 2004). Based on the characterisitic, Loisel et al. (2006) used remotely sensed spectral slope of $b_{\mathrm{bp}}(\lambda), \gamma$, as a particle size index and mapped global distribution of $\gamma$ using SeaWiFS imagery. MontesHugo et al. (2008) assessed the relationship between $\gamma$ and phytoplankton cell size for the Western Antarctic Peninsula region. They showed that $\gamma$ could act as an optical index of the dominance of microphytoplankton ( $>20 \mu \mathrm{m}$ in size). Kostadinov et al. (2009) also quantified the relationship between $\gamma$ and particle size distribution (PSD) and showed the application study to satellite remote sensing discussing with phytoplankton sizes. 
Table 1. List of symbols and units.

\begin{tabular}{lll}
\hline Abbreviation & Definition & $\mathrm{Unit}$ \\
\hline$a_{\mathrm{t}}$ & Total absorption coefficient & $\mathrm{m}^{-1}$ \\
$a_{\mathrm{W}}$ & Water absorption coefficient & $\mathrm{m}^{-1}$ \\
$a_{\mathrm{p}}$ & Particle absorption coefficient & $\mathrm{m}^{-1}$ \\
$a_{\mathrm{NAP}}$ & Non-algal particle absorption coefficient & $\mathrm{m}^{-1}$ \\
$a_{\mathrm{CDOM}}$ & CDOM absorption coefficient & $\mathrm{m}^{-1}$ \\
$a_{\mathrm{dg}}$ & The sum of $a_{\mathrm{NAP}}$ and $a_{\mathrm{CDOM}}$ & $\mathrm{m}^{-1}$ \\
$a_{\mathrm{ph}}$ & Phytoplankton absorption coefficient & $\mathrm{m}^{-1}$ \\
$b_{\mathrm{b}}$ & Backscattering coefficient & $\mathrm{m}^{-1}$ \\
$b_{\mathrm{bp}}$ & Particle backscattering coefficient & $\mathrm{m}^{-1}$ \\
$b_{\mathrm{bw}}$ & Water backscattering coefficient & $\mathrm{m}^{-1}$ \\
$\beta$ & Volume scattering function & $\mathrm{sr}^{-1} \mathrm{~m}^{-1}$ \\
$E_{\mathrm{d}}$ & Downwelling irradiance & $\mathrm{Wm}^{-2} \mathrm{~nm}^{-1}$ \\
$\gamma$ & Spectral slope of $b_{\mathrm{bp}}$ & $\mathrm{nm}^{-1}$ \\
$L_{\mathrm{u}}$ & Upwelling radiance & $\mathrm{Wm}^{-2} \mathrm{sr}^{-1} \mu \mathrm{m}^{-1}$ \\
$L_{\mathrm{W}}$ & Water-leaving radiance & $\mathrm{Wm}^{-2} \mathrm{sr}^{-1} \mu \mathrm{m}^{-1}$ \\
$\lambda$ & Wavelength & $\mathrm{nm}^{-1}$ \\
$R_{\mathrm{rs}}$ & Surface remote sensing reflectance & $\mathrm{sr}^{-1}$ \\
$\mathrm{OD}$ & Optical density & \\
$S$ & Spectral slope of $a_{\mathrm{dg}}$ & $\mathrm{nm}^{-1}$ \\
$F_{\mathrm{L}}$ & Phytoplankton size index & $\%$ \\
$\mathrm{AP}$ & Accessory pigment & $\mathrm{mg} \mathrm{m}^{-3}$ \\
$\mathrm{DP}$ & Diagnostic pigment & \\
$\mathrm{TAP}$ & Total accessory pigment concentration & $\mathrm{mg} \mathrm{m}^{-3}$ \\
$\mathrm{TP}$ & Total pigment concentration & \\
\hline & & \\
\hline
\end{tabular}

On the other hand, direct satellite measurement of the IOPs is impossible; therefore, they must be estimated using $L_{\mathrm{w}}$. To apply an IOP-based PFT estimation model to satellite remote sensing data, other optical models for estimating IOPs are required. Several IOP models have been reported (e.g. Carder et al., 1999; Sathyendranath et al., 2001; Lee et al., 2002; Smyth et al., 2006). Note that IOPs are specific to regional water and vary with the water components, such as phytoplankton taxa, suspended particles, or dissolved organic materials. Therefore, IOP models should be fully validated and tuned using data in the area where they are applied (Wang et al., 2005). Sathyendranath et al. (2004) reported, for example, that the algorithm developed for the North West Atlantic Zone to identify diatom blooms should be tuned when it is applied to other regions because of variations in the optical properties of diatoms. Wang and Cota (2003) also suggested that proposed IOP models should be empirically tuned for the study regions before their use. Little is known about the quantitative relationship between PFTs and IOPs in the Chukchi and Bering Sea shelf region. Thus, it is necessary to quantify the optical properties of phytoplankton assemblages and other components of the water in order to use satellite data to monitor the spatial distribution of PFTs in the area.
To elucidate the mechanism of ecosystem changes due to recent environmental changes in the Chukchi and Bering Sea shelf, we emphasize the importance of monitoring the temporal and spatial distribution of phytoplankton-size-specific biomass, which is a major factor in determining the number of trophic levels. However, it is not clear how variations in phytoplankton size structure affect the optical properties of seawater in the region. Moreover, an optical model for estimating phytoplankton size structure suitable for the area has not yet been developed. We therefore developed a size derivation model (SDM) for estimating the phytoplankton size structure index $\left(F_{\mathrm{L}}\right)$ (defined as the fraction of largercelled phytoplankton $[>5 \mu \mathrm{m}]$ in the total assemblage) by assessing the relationship between $F_{\mathrm{L}}$ and the optical properties (absorption and backscattering). In this paper, we propose an SDM that adopts multiple regression models using two different optical variables and show the accuracy of phytoplankton size estimates. Finally, we evaluated whether the model can be used to improve biogeochemical knowledge. 


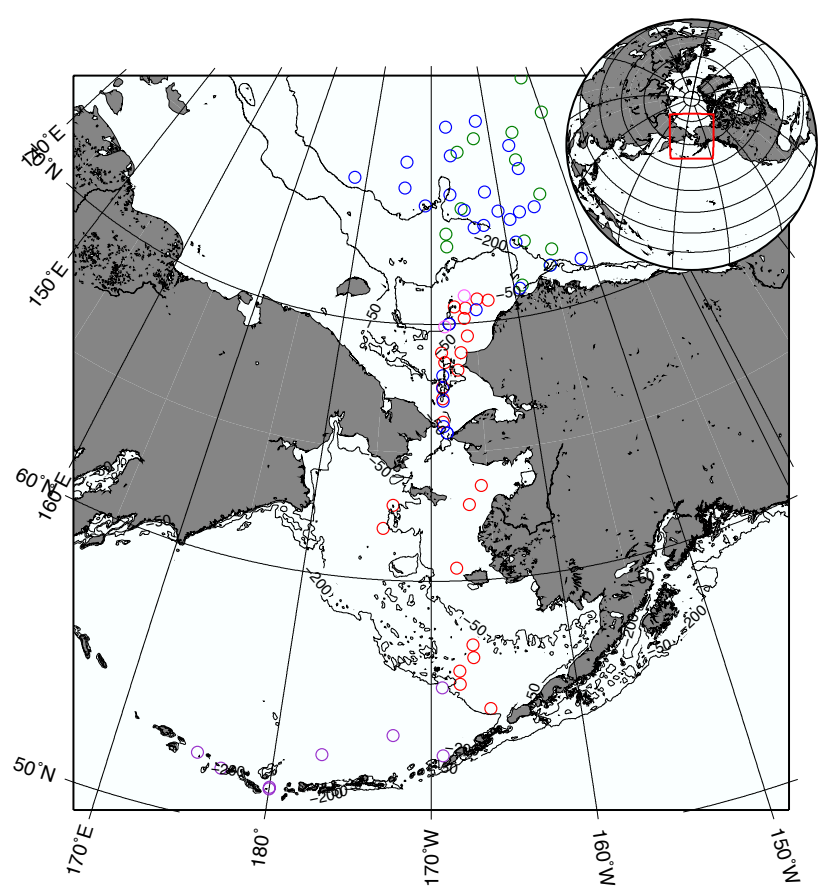

Fig. 1. Location of 75 stations that in situ data were obtained for this study. Data for SDM development were sampled during the OS180 (red circles) and those for SDM validation were sampled during the OS190 (pink circles), KH09-4 (purple circles) and MR10-05 (blue circles). Bathymetry contours indicated are 50- and 200-m intervals.

\section{Materials and methods}

\subsection{Study sites}

Data for the present study were sampled in the continental shelf region of the Chukchi and Bering Seas (Fig. 1). In situ data for developing the SDM were sampled during a cruise of the T/S Oshoro-maru (Hokkaido University) in summer 2007 (OS180 cruise). There were 22 sampling stations, 10 in the Bering Sea and 12 in the Chukchi Sea (Fig. 1). In addition, samples used to validate the SDM accuracy were collected during the cruises of the T/S Oshoro-maru in the early summer 2008 (OS190 cruise), the R/V Mirai (Japan Agency for Marine-Earth Science and Technology, JAMSTEC) in the late summer 2009 (MR09-03 cruise) and 2010 (MR1005 cruise), and R/V Hakuho-maru (JAMSTEC) in summer 2009 (KH09-4 cruise). There were 2, 14, 31, and 8 sampling stations in the study region, respectively, for each cruise (Fig. 1).

\subsection{Size fractionated phytoplankton pigments analysis}

The biomass of phytoplankton assemblages was defined in terms of chl- $a$ level. The concentrations of size-fractionated chl- $a$ and other phytoplankton pigments for SDM development were determined by high-performance liquid chro-
Table 2. Major taxonomically significant pigments in phytoplankton groups and their abbreviations (Jeffrey and Vesk, 1997) and definitions of four major algal assemblages determined by pigment composition (Aiken et al., 2007).

\begin{tabular}{|c|c|}
\hline Pigment & Specificity \\
\hline Peridinin (Peri) & Dinoflagellates \\
\hline $19^{\prime}$-butanoyloxyfucoxanthin $\left(19^{\prime}-\mathrm{BF}\right)$ & $\begin{array}{l}\text { Haptophytes } 3 \text { and } 4 \text {, } \\
\text { chrysophytes }\end{array}$ \\
\hline Fucoxanthin (Fuco) & $\begin{array}{l}\text { Diatoms, haptophytes } 1 \text {, } \\
2,3 \text { and } 4 \text {, chrysophytes }\end{array}$ \\
\hline $19^{\prime}$-hexanoyloxyfucoxanthin $\left(19^{\prime}-\mathrm{HF}\right)$ & Haptophytes 3 and 4 \\
\hline Alloxanthin (Allo) & Chrysophytes \\
\hline Zeaxanthin (Zea) & Chlorophytes \\
\hline Chlorophyll- $b$ (chl- $b$ ) & Chlorophytes \\
\hline Chlorophyll- $a$ (chl- $a$ ) & All groups \\
\hline Fuco/TAP & Diatoms \\
\hline Peri/TAP & Dinoflagellates \\
\hline$\left(19^{\prime}-\mathrm{BF}+19^{\prime}-\mathrm{HF}+\mathrm{Allo}+\mathrm{chl}-b\right) / \mathrm{TAP}$ & Flagellates \\
\hline Zea/TAP & Procaryotes \\
\hline
\end{tabular}

matography (HPLC). Water samples for HPLC were collected from six fixed depths, $0,10,20,30,50$, and $75 \mathrm{~m}$ or six light depths $(100,50,25,10,5$, and $1 \%$ penetration of surface photosynthetically available radiation) with $\mathrm{CTD} /$ carousel samplers. The light depths were determined by a quantum sensor (LI-193SA, LI-COR). The samples were passed through 20- and 5- $\mu \mathrm{m}$ nylon mesh filters and Whatman GF/F filters ( $47 \mathrm{~mm}$ in diameter) under gentle vacuum $(<0.013 \mathrm{MPa})$. Filters were stored in liquid nitrogen until analysis in the laboratory. Filter samples were broken into pieces and soaked in $5 \mathrm{ml} N^{\prime} N$-dimethylformamide (DMF) containing canthaxanthin as an internal standard. The extraction and detection of phytoplankton pigments are described in detail in Suzuki et al. (2005). We selected seven major pigments on the basis of comparable studies that referred to the relationship between cell size and pigment composition (Vidussi et al., 2001): fucoxanthin (Fuco), peridinin (Peri), 19'-hexanoyloxyfucoxanthin (19'-HF), 19' butanoyloxyfucoxanthin (19'-BF), alloxanthin (Allo), zeaxanthin (Zea), total chlorophyll- $b$ (chl- $b$ ), and also chl- $a$. The pigments are typical of phytoplankton groups and are often used as biomarkers (e.g. Jeffrey and Vesk, 1997, Table 2). Following the method of Aiken et al. (2007) as described in Table 2, we simply estimated the fraction of four major phytoplankton assemblages (diatoms, dinoflagellates, nanoflagellates and prokaryotes) in the total algal biomass using HPLC pigment composition. For SDM validation, sizefractionated chl- $a$ concentrations at the surface sampled during the OS190, MR09-03, KH09-4, and MR10-05 cruises were determined by a fluorometric method with a Turner Designs model 10-AU fluorometer (Welschmeyer, 1994). The sample water was passed through 20- and 5- $\mu$ m nylon mesh filters and GF/F filters ( $47 \mathrm{~mm}$ in diameter) on the OS190, 
10- and 2- $\mu \mathrm{m}$ pore-size Whatman Nuclepore and GF/F filters on the KH09-4, and 10-, 5-, 2- $\mu \mathrm{m}$ Nuclepore and GF/F filters on the MR09-03 and the MR10-05.

We define the phytoplankton size index $F_{\mathrm{L}}$ as

$F_{\mathrm{L}}=\frac{\mathrm{chl}-a_{>5 \mu \mathrm{m}}}{\operatorname{chl}-a_{\text {total }}} \cdot 100[\%]$,

where chl- $a_{>5} \mu \mathrm{m}$ and chl- $a_{\text {total }}$ indicate chl- $a$ larger than $5 \mu \mathrm{m}$ and the sum of chl- $a$ of all sizes, respectively. Chl$a$ was not measured using a mesh with $5-\mu \mathrm{m}$ pore size on KH09-4; therefore chl- $a$ larger than $10 \mu \mathrm{m}$ (chl- $a_{>10 \mu \mathrm{m}}$ ) to chl- $a_{\text {total }}$ ratio was converted to chl- $a_{>5} \mu \mathrm{m}$ to chl- $a_{\text {total }}$ ratio by an empirical equation using surface-size-fractionated chl$a$ data obtained on MR09-03 and MR10-05,

$$
\begin{aligned}
& \frac{\text { chl }-a_{>5 \mu \mathrm{m}}}{\text { chl }-a_{\text {total }}}=A_{0}+A_{1} \frac{\text { chl }-a_{>10 \mu \mathrm{m}}}{\text { chl }-a_{\text {total }}}+A_{2} \frac{\text { chl }-a_{>10 \mu \mathrm{m}}{ }^{2}}{\text { chl }-a_{\text {total }}} \\
& \quad+A_{3} \frac{\text { chl }-a_{>10 \mu \mathrm{m}}{ }^{3}}{\text { chl }-a_{\text {total }}},
\end{aligned}
$$

where $A_{0}=0.003, A_{1}=1.504, A_{2}=-1.080$, and $A_{3}=$ 0.605 . These two chl- $a$ ratios were tightly co-varied $\left(r^{2}=\right.$ $0.97)$.

\subsection{Bio-optical observations}

Absorption coefficients and backscattering coefficients were obtained in this study. Samples used for determining the spectral absorption coefficients of suspended particles $a_{\mathrm{p}}(\lambda)$ and of colored dissolved organic matter (CDOM) $a_{\mathrm{CDOM}}(\lambda)$ were taken from the same water as the HPLC samples. The samples for measuring $a_{\mathrm{p}}(\lambda)(200-4000 \mathrm{ml})$ and $a_{\mathrm{CDOM}}$ $(250 \mathrm{ml})$ were both gently filtered $(<0.013 \mathrm{MPa})$ : through a Whatman GF/F filter $\left(25 \mathrm{~mm}\right.$ in diameter) for $a_{\mathrm{p}}(\lambda)$ and through a Whatman Nuclepore filter with $0.2-\mu \mathrm{m}$ pore size (47 mm in diameter) for $a_{\mathrm{CDOM}}(\lambda)$. The optical density (OD, dimensionless) of the collected particles was measured immediately using an MPS2450 spectrophotometer (Shimadzu) between 350 and $750 \mathrm{~nm}$ in $1 \mathrm{~nm}$ increments. A GF/Ffiltered sample was rinsed and soaked in methanol to extract pigments (Kishino et al., 1985), and the OD of nonalgal particles (NAPs) was re-measured. Then the absorption coefficients of total suspended particles, $a_{\mathrm{p}}(\lambda)$ and $a_{\mathrm{NAP}}(\lambda)$, were calculated, using the correction of the path length amplification due to multiple scattering inside the filter given in Cleveland and Weidemann (1993). The absorption of phytoplankton cells, $a_{\mathrm{ph}}(\lambda)$, was obtained by subtracting $a_{\mathrm{NAP}}(\lambda)$ from $a_{\mathrm{p}}(\lambda)$. The OD of filtered samples used to determine $a_{\mathrm{CDOM}}(\lambda)$ was measured immediately with the MPS2450 instrument and was calculated as $a_{\mathrm{CDOM}}(\lambda)$ by a the method described in a SeaWiFS technical report (Pegau et al., 2003).

The vertical distribution $(0-80 \mathrm{~m})$ of the volume scattering functions $\beta(\theta)$ for three angles $\left(\theta=100,125\right.$, and $\left.150^{\circ}\right)$ at three wavelengths $(440,531$, and $660 \mathrm{~nm})$ was also measured using an in-water VSF meter (Eco-VSF3P, WET Labs).
This measurement was done immediately after water sampling. The particle backscattering coefficient $b_{\mathrm{bp}}(\lambda)$ was estimated from $\beta(100)$ using a $\chi$ value that is a factor proportionally between $b_{\mathrm{bp}}(\lambda)$ and $\beta(\theta)$, as proposed by Maffione and Dana (1997),

$b_{\mathrm{bp}}(\lambda)=2 \pi \times \beta\left(100^{\circ}, \lambda\right)$,

where $\chi=0.86$ according to the value obtained empirically in Sullivan and Twardowski (2009). The general spectral shape of $b_{\mathrm{bp}}(\lambda)$ can be approximated functionally (e.g. Smith and Baker, 1981; Sathyendranath et al., 2001):

$b_{\mathrm{bp}}(\lambda)=b_{\mathrm{bp}}\left(\lambda_{0}\right)\left(\frac{\lambda_{0}}{\lambda}\right)^{\gamma}$,

where $\lambda_{0}$ is a reference wavelength, which is set to $555 \mathrm{~nm}$ in this study, and $\gamma$ is the spectral slope. We determined the values of $\gamma$ for the water at each sampled depth by a least squares method fitted to $b_{\mathrm{bp}}(\lambda)$ at three wavelengths.

Vertical profiles of downwelling irradiance $E_{\mathrm{d}}(\lambda)$ and upwelling radiance $L_{\mathrm{u}}(\lambda)$ were measured. These data were collected using two optical instruments, a HyperPro freefall profiler (Satlantic, Inc.) during the OS180 and OS190 cruises, and a PRR800/810 free-fall profiler (Biospherical Instruments Inc.) during the MR09-03, KH09-4, and MR10-05 cruises. The spectral remote sensing reflectance $R_{\mathrm{rs}}(\lambda)$ was calculated as the ratio of the water-leaving radiance $L_{\mathrm{w}}(\lambda)$ to $E_{\mathrm{d}}(\lambda)$ just above the water (Darecki and Stramski, 2004),

$R_{\mathrm{rS}}(\lambda)=\frac{L_{\mathrm{w}}\left(\lambda, 0^{+}\right)}{E_{\mathrm{d}}\left(\lambda, 0^{+}\right)}=0.544 \frac{L_{\mathrm{u}}\left(\lambda, 0^{-}\right)}{E_{\mathrm{d}}\left(\lambda, 0^{+}\right)}$,

where 0.544 is a water-air interface propagation factor.

\subsection{Quantification of phytoplankton size and community structure using IOPs}

We investigated the quantitative relationships between phytoplankton size structure index $F_{\mathrm{L}}$ and the IOPs. First, we assessed the relationship between $F_{\mathrm{L}}$ and the absorption properties. Several studies have already established that the ratio of $a_{\mathrm{ph}}(\lambda)$ at different wavelengths, such as blue and red light, can be used as an indicator to assess the abundance of accessory pigments relative to total chl- $a$. Accessory pigment composition varies with the phytoplankton taxa and is related to nutrient conditions (e.g. Ciotti et al., 2002; Fishwick et al., 2006); large-celled diatoms tend to be dominant in eutrophic regimes, and small prokaryotes are important in oligotrophic regimes (Chisholm, 1992).

On the other hand, we also evaluated the relationship between $F_{\mathrm{L}}$ and $\gamma$ in accordance with the method and theories proposed by Montes-Hugo et al. (2008). According to the Mie theory, $\gamma$ increases as the mean particle size decreases. To investigate the variation in particle backscattering with algal cell size composition, $b_{\mathrm{bp}}(\lambda)$ data from turbid water were omitted. Turbid water was defined as that in which 
Table 3. Regression coefficients and determination coefficients $\left(r^{2}\right)$ between $F_{\mathrm{L}}$ and IOPs, $a_{\mathrm{ph}}(443) / a_{\mathrm{ph}}(667), a_{\mathrm{ph}}(488) / a_{\mathrm{ph}}(555)$, and $\gamma$. All $p$-values were less than 0.01. RMSE are also provided. Values in parentheses are $95 \%$ confidence intervals of each RMSE, which were computed assuming exponential distribution to the square errors.

\begin{tabular}{lrrr}
\hline & $a_{\mathrm{ph}}(443) / a_{\mathrm{ph}}(667)$ & $a_{\mathrm{ph}}(488) / a_{\mathrm{ph}}(555)$ & $\gamma$ \\
\hline slope & -32.43 & -15.07 & -19.15 \\
intercept & 119.6 & 89.20 & 98.26 \\
$r^{2}$ & 0.58 & 0.52 & 0.60 \\
RMSE & $18.20(15.85-20.87)$ & $19.27(16.78-22.10)$ & $17.68(15.40-20.28)$ \\
$N$ & 77 & 77 & 77 \\
\hline
\end{tabular}

the contribution of $a_{\mathrm{NAP}}(443)$ to the total absorption coefficient $a_{\mathrm{t}}(443)$ was greater than that of $a_{\mathrm{ph}}(443)$. Then, we attempted to quantify $F_{\mathrm{L}}$ empirically using these IOPs.

\subsection{SDM validations and application}

To apply the SDM to satellite remote sensing estimation of the IOPs, $a_{\mathrm{ph}}(\lambda)$ and $\gamma$ are needed as model inputs. The $a_{\mathrm{ph}}(\lambda)$ value at the sea surface was derived from $R_{\mathrm{rs}}(\lambda)$ using the quasi-analytical algorithm (QAA) proposed by Lee et al. (2002). The QAA uses several calculation processes and yields $a_{\mathrm{ph}}(\lambda)$ as the final product. We used the latest version of the QAA (version 5, QAA-v5), in which the empirical calculation steps, Tables 2 and 3 in Lee et al. (2002), have been updated (Lee et al., 2009). For the calculation step 8 of the QAA, the spectral slope $S$ of $a_{\mathrm{dg}}(\lambda)$ (the sum of the $a_{\mathrm{CDOM}}[\lambda]$ and $a_{\mathrm{NAP}}[\lambda]$ values) was tuned for the study region empirically using data obtained on OS180. On the other hand, $\gamma$ was derived from $R_{\mathrm{rS}}(488) / R_{\mathrm{rS}}(555)$, which was used to derive $\gamma$ in Lyon and Hoge (2006):

$\gamma=2.092+9.577 R_{0}-17.67 R_{0}^{2}+11.10 R_{0}^{3}$

where $R_{0}=\ln \left(R_{\mathrm{rS}}(488) / R_{\mathrm{rS}}(555)\right)$. The coefficients in Eq. (6) were empirically determined using in situ $\gamma$ and $R_{\mathrm{rS}}(\lambda)$ values measured with the VSF3P and Hyper-OCR instruments. The estimation performance of the SDM was also examined using $R_{\mathrm{rs}}(\lambda)$ data obtained during the OS190, MR09-03, KH09-4, and MR10-05 cruises.

We applied the SDM to satellite data. The MODIS/Aqua Level 3 binned remote sensing reflectance $R_{\mathrm{rs}}(\lambda)$ and sea surface temperature (SST) data (reprocessing version 2010.0) were downloaded from the Distributed Active Archive Center (DAAC) of Goddard Space Flight Center (GSFC), NASA. Daily data were obtained. The input parameters for the SDM were derived from the $R_{\mathrm{rs}}(\lambda)$ data at wavelengths of 412, 443, 488, 555, and $667 \mathrm{~nm}$ using QAA-v5 and Eq. (6). Then, $F_{\mathrm{L}}$ was derived for each frame of the remotely sensed satellite images. The satellite chl- $a$ was also calculated from $R_{\mathrm{rs}}(\lambda)$ using the Arctic OC4L algorithm (Eq. 7) (Cota et al., 2004) which is optimized for highly packaged data resulting from large, shade-acclimated phytoplankton at the high latitudes (Cota et al., 2003):

chl- $a=10^{0.592-3.607 R,}$

where the maximum band $R_{\mathrm{rS}}(\lambda)$ ratio $R=\log \left(R_{\mathrm{rS}}[443]>\right.$ $\left.R_{\mathrm{rs}}[488] / R_{\mathrm{rs}}[555]\right)$. Finaly, all the daily satelltie products were composited as monthly average.

\section{Results and discussion}

\subsection{Empirical relationships between $F_{L}$ and IOPs}

$F_{\mathrm{L}}$ was quantified empirically by analyzing the correlation using the $a_{\mathrm{ph}}(\lambda)$ ratios $a_{\mathrm{ph}}(443) / a_{\mathrm{ph}}(667)$ and $a_{\mathrm{ph}}(488) / a_{\mathrm{ph}}(555)$, and $\gamma$ (Fig. 2a-c). The $a_{\mathrm{ph}}(443) / a_{\mathrm{ph}}(667)$ value was identified as the $a_{\mathrm{ph}}(\lambda)$ ratio because it can roughly express the ratio of total algal pigments to total chl- $a$ : light at $443 \mathrm{~nm}$ is absorbed by most phytoplankton pigments (chlorophylls, photosynthetic and non-photosynthetic carotenoids), but light at $667 \mathrm{~nm}$ is mainly absorbed only by chl- $a$ (Bidigare et al., 1990). In addition, $488 \mathrm{~nm}$ is an absorption band for various carotenoids, and $555 \mathrm{~nm}$ is the smallest absorption band for algal pigments (Bidigare et al., 1990). Thus, $a_{\mathrm{ph}}(488) / a_{\mathrm{ph}}(555)$ can be used as an indicator to assess the abundance of carotenoids (the sum of the diagnostic pigments). The statistical relationships between $F_{\mathrm{L}}$ and the IOPs are shown in Table 3. The relationship between $F_{\mathrm{L}}$ and $a_{\mathrm{ph}}(443) / a_{\mathrm{ph}}(667)$ is similar to that reported by Fishwick et al. (2006) for the Benguella upwelling region. Fishwick et al. (2006) showed that the chl- $a$-to-totalpigment ratio (chl- $a / \mathrm{TP})$ is significantly and positively correlated with $a_{\mathrm{ph}}(676) / a_{\mathrm{ph}}(440)$ (note that this is the inverse of the ratio used in this study). Diatoms and dinoflagellates, which are generally classified as microphytoplankton (Vidussi et al., 2001), exhibited higher values of chl- $a$ /TP and $a_{\mathrm{ph}}(676) / a_{\mathrm{ph}}(440)$ than smaller phytoplankton groups, that is, flagellates. The total-pigment-to-chl- $a$ ratio roughly indicated by $a_{\mathrm{ph}}(443) / a_{\mathrm{ph}}(667)$ in this study was significantly correlated with dominant cell size in the study area (Fig. 2a). Since a similar relationship with $F_{\mathrm{L}}$ was also found for $a_{\mathrm{ph}}(488) / a_{\mathrm{ph}}(555)$, it can be said that detection of the abundance of accessory pigments is important for optically assessing the cell size structure of the phytoplankton community. The effect of pigmentation is an important factor that reflects the cell size structure of a phytoplankton community (Ciotti et al., 2002). However, it does not represent the true cell size compositions because the $a_{\mathrm{ph}}(\lambda)$ ratios actually reflect the algal pigment composition, which tends to vary with their cell size. Therefore, the use of the $a_{\mathrm{ph}}(\lambda)$ ratio as an independent variable in the SDM leads to overestimation of $F_{\mathrm{L}}$ when groups of small phytoplankton, such as small-sized diatoms, which do not contain many carotenoids compared to autotrophic flagellates (Wright and Jeffrey, 2006), are dominant in the water. Although high $F_{\mathrm{L}}$ with a low $a_{\mathrm{ph}}(\lambda)$ 

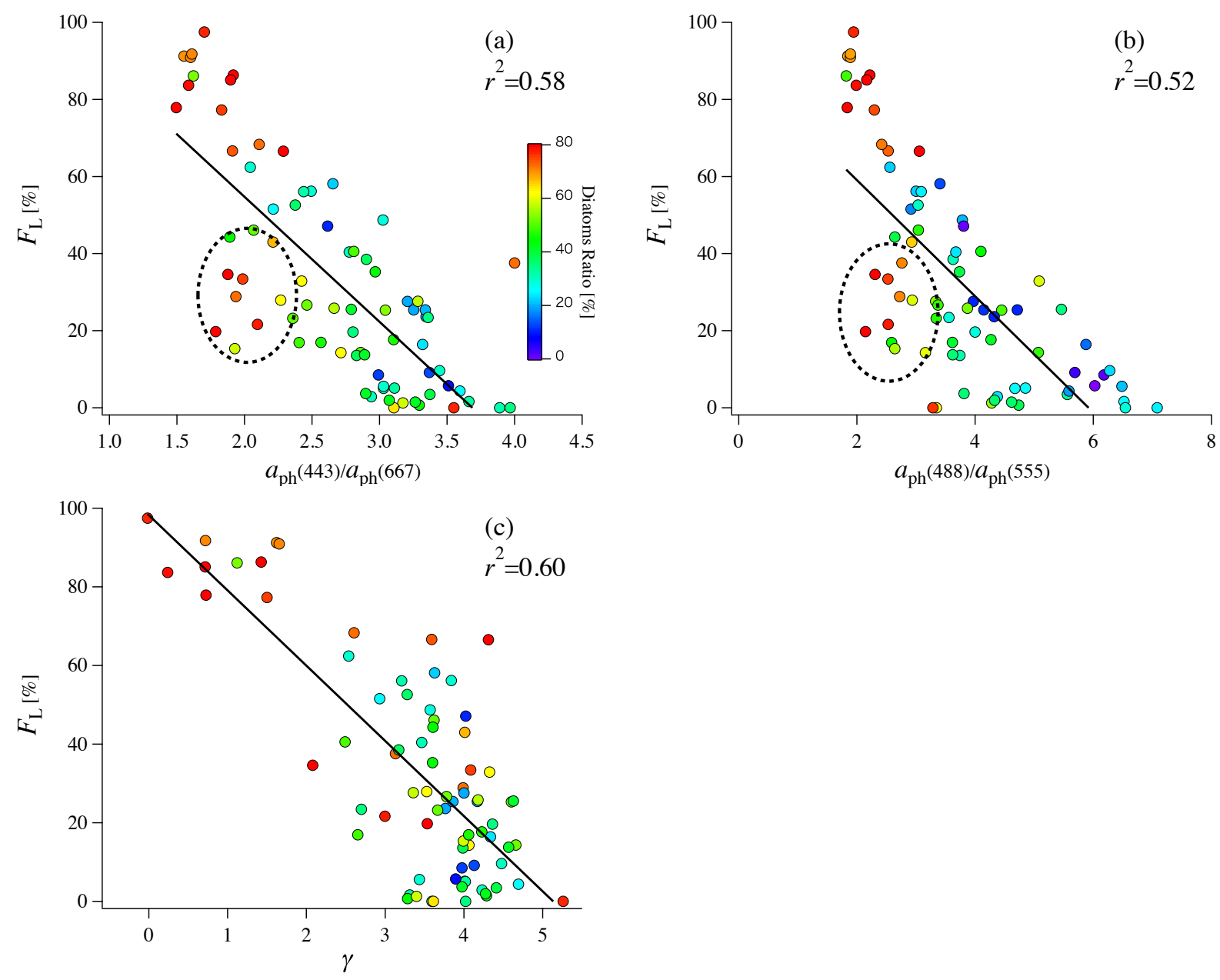

Fig. 2. Variation of in situ $F_{\mathrm{L}}$ as a function of (a) in situ $a_{\mathrm{ph}}(443) / a_{\mathrm{ph}}(667)$, (b) in situ $a_{\mathrm{ph}}(488) / a_{\mathrm{ph}}(555)$ and (c) in situ $\gamma$. Colors in each plot correspond to diatom fraction calculated by HPLC pigment composition (Aiken et al., 2007). Dashed circles indicate samples whose diatom fraction is relatively high inpite of their relatively low $F_{\mathrm{L}}$ values. Solid lines indicate regression lines and their slope and intercept values are descirbed in Table 3 .

ratios co-occurs with high fucoxanthin (Fuco/TAP), communities of small phytoplankton containing relatively high Fuco/TAP ratios (which are expected to be small diatoms) are also found at low $F_{\mathrm{L}}$ with a low $a_{\mathrm{ph}}(\lambda)$ ratio (dotted circle in Fig. 2a and b). Thus, to derive $F_{\mathrm{L}}$ more accurately using a model, the optical properties of small-sized diatoms must be considered. One way to distinguish such small-sized diatoms is to use $\gamma$.

Figure $2 \mathrm{c}$ shows the relationship between $F_{\mathrm{L}}$ and $\gamma$. Theoritical and experimental relationship between $\gamma$ and particle size or size distribution have been reported (e.g. Raynolds et al., 2001; Green and Sosik, 2004; Wozniak and Stramski, 2004; Kostadinov et al., 2009). As we 11 as these study we obtained a good correlation between $F_{\mathrm{L}}$ and $\gamma$, which is higher than between $F_{\mathrm{L}}$ and the $a_{\mathrm{ph}}(\lambda)$ ratios (Table 3 ). Note that data with high Fuco/TAP do not tend to be converged as seen in Fig. 2a and b, and they are evenly distributed except in the high $F_{\mathrm{L}}$ domain (Fig. 2c). Montes-Hugo et al. (2008) showed a similar relationship between dominant phytoplankton size and $\gamma$ in the Western Antarctic Peninsula region. They demonstrated that $\gamma$ can be a good indicator for determining the dominance of microphytoplankton larger than $20 \mu \mathrm{m}$. Our results suggest that micro- and nanophytoplankton in the present study (defined as larger than $5 \mu \mathrm{m}$ ) can also be approximately estimated by $\gamma$ in our study region (Fig. 2c). However, the problem with using $\gamma$ as the single variable to derive $F_{\mathrm{L}}$ is that the presence of NAPs might cause errors. In that case, extraction of the backscattering coefficient of phytoplankton cells is required for accurate estimation of $F_{\mathrm{L}}$, though that would be difficult at present.

The $a_{\mathrm{ph}}(\lambda)$ ratio determined by pigment composition indicates the physiological properties, which tend to vary with phytoplankton cell size (Ciotti et al., 2002). On the other hand, $\gamma$ is determined by the average diameter of suspended particles including NAPs and is influenced by the geometry of the phytoplankton cells rather than their pigment 
Table 4. Regression coefficients for SDM (Eq. 8) when $a_{\mathrm{ph}}(443) / a_{\mathrm{ph}}(667)$ and $\gamma$ were used, and when $a_{\mathrm{ph}}(488) / a_{\mathrm{ph}}(555)$ and $\gamma$ were used. Values in parentheses are $95 \%$ confidence intervals of each coefficient. RMSE are also provided. Values in parentheses are $95 \%$ confidence intervals of each RMSE, which were computed assuming exponential distribution to the square errors.

\begin{tabular}{lrr}
\hline & $a_{\mathrm{ph}}(443) / a_{\mathrm{ph}}(667)$ and $\gamma$ & $a_{\mathrm{ph}}(488) / a_{\mathrm{ph}}(555)$ and $\gamma$ \\
\hline$X_{0}$ & $-1.056(-2.253-0.011)$ & $-0.570(-1.311-0.015)$ \\
$X_{1}$ & $-0.591(-1.302-0.040)$ & $-0.565(-1.283-0.070)$ \\
$X_{2}$ & $4.001(1.618-6.833)$ & $3.175(1.267-5.519)$ \\
$R^{2}$ & 0.72 & 0.71 \\
RMSE & $14.76(12.85-16.92)$ & $14.89(12.97-17.08)$ \\
$N$ & 77 & 77 \\
\hline
\end{tabular}

composition. Hence, although the $a_{\mathrm{ph}}(\lambda)$ ratio and $\gamma$ are not completely independent, their variations with $F_{\mathrm{L}}$ can be different.

Despite the problems with deriving $F_{\mathrm{L}}$ using the IOPs mentioned above, a multiple regression model using both the $a_{\mathrm{ph}}(\lambda)$ ratio and $\gamma$ as independent variables is an effective method for deriving the true algal size. To improve the SDM's accuracy, we selected the multiple logistic regression model and fitted to the in situ $F_{\mathrm{L}}, a_{\mathrm{ph}}(\lambda)$ ratio, and $\gamma$ data,

$$
F_{\mathrm{L}}=\frac{1}{1+\exp \left[-\left(X_{0} \frac{a_{\mathrm{ph}}\left(\lambda_{1}\right)}{a_{\mathrm{ph}}\left(\lambda_{2}\right)}+X_{1} \gamma+X_{2}\right)\right]} \cdot 100[\%],
$$

where $X_{0}, X_{1}$ and $X_{2}$ represent the regression coefficients of the model, as listed in Table 4, and $\lambda_{1}$ and $\lambda_{2}$ represent the wavelengths of the $a_{\mathrm{ph}}(\lambda)$ ratio, which can indicate algal pigmentation. The $r^{2}$ values rose to 0.72 and 0.71 when Eq. (8) was fitted to $a_{\mathrm{ph}}(443) / a_{\mathrm{ph}}(667)$ and $\gamma$, and $a_{\mathrm{ph}}(488) / a_{\mathrm{ph}}(555)$, respectively. The root mean square errors (RMSEs) also became smaller (Tables 3 and 4). Note that a logistic regression model is suitable for representing the variation in $F_{\mathrm{L}}$ because it has an upper limit of $100 \%$ and a lower limit of $0 \%$. Using the model, we successfully avoided unrealistic values of $F_{\mathrm{L}}$ (such as negative values and those higher than $100 \%$ ) when we applied it to unknown remotely sensed ocean color data. Thus, we proposed application of Eq. (8) as the SDM to satellite remote sensing data for deriving $F_{\mathrm{L}}$.

\subsection{SDM validation}

The accuracy of the SDM was validated using in situ $R_{\mathrm{rs}}(\lambda)$ data to avoid the effect of atmospheric correction errors or surface effects such as whitecaps and sun glint. In this study, $a_{\mathrm{ph}}(488) / a_{\mathrm{ph}}(555)$ was used as the SDM input (Eq. 8) because the estimation accuracy of $a_{\mathrm{ph}}(667)$ could be worse compared with that at shorter wavelengths $(<555 \mathrm{~nm})$ because $a_{\mathrm{t}}(\lambda)$ is dominated by $a_{\mathrm{w}}(\lambda)$. Figure 3 compares the retrieved $F_{\mathrm{L}}$ and $F_{\mathrm{L}}$ sampled in situ at the sea surface. Fifty-

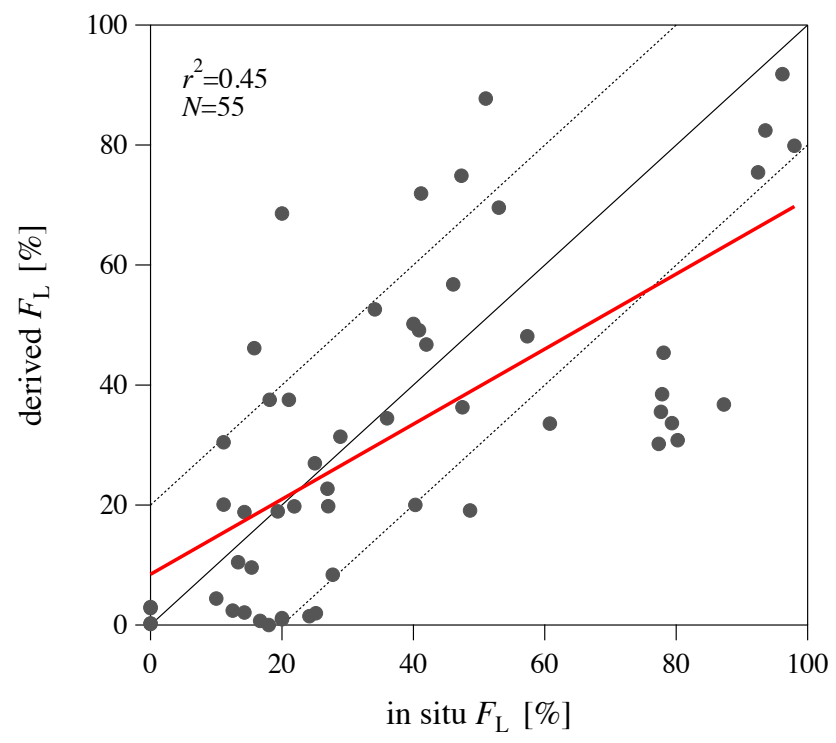

Fig. 3. Comparison of SDM-derived $F_{\mathrm{L}}$ and in situ $F_{\mathrm{L}}\left(r^{2}=0.45\right.$, $p<0.0001$, RMSE $=22.7, N=55)$. Solid red line represents the regression line $($ slope $=0.63$, intercept $=8.46$ ), the solid black line indicates the 1:1 line, and the dashed lines indicate the $\pm 20 \% F_{\mathrm{L}}$ range with respect to the $1: 1$ line. 38 out of 55 validated data are correctly derived within $\pm 20 \% F_{L}$ range (success rate of $69 \%$ ).

five data points were used for this examination (distinct from the data used for SDM development). The SDM successfully derived 38 of $55(69 \%)$ validated data within $\pm 20 \%$ $F_{\mathrm{L}}$ range (Fig. 3). A comparison of the SDM's accuracy with that of other phytoplankton size-retrieving models using the RMSE (Ciotti and Bricaud, 2006; Mouw and Yoder, 2010) revealed that the SDM exhibited a slightly worse RMSE of $22.7 \%$ than that found by Ciotti and Bricaud (2006) (RMSE $17.2 \%$ ) and Mouw and Yoder (2010) (RMSE $12.6 \%$ ). However, the SDM successfully derived $F_{\mathrm{L}}$ with sufficient accuracy even in the Chukchi Sea, which is known as optically complex water owing to the high proportion of $a_{\mathrm{CDOM}}(\lambda)$ to $a_{\mathrm{t}}(\lambda)$ (Pegau, 2002; Wang et al., 2005). Although the SDM's estimation accuracy for $F_{\mathrm{L}}$ can be improved, the SDM has the advantage of deriving phytoplankton size structures by a ratio expressing the existence of nano- and microphytoplankton using a simple equation (Eq. 8). Since the SDM was developed empirically using in situ IOPs, the $a_{\mathrm{ph}}(\lambda)$ ratio and $\gamma$, which co-vary with the phytoplankton size, accurate estimation of the IOPs results in successful $F_{\mathrm{L}}$ derivation. In addition, our result shows that $a_{\mathrm{ph}}(443) / a_{\mathrm{ph}}(667)$, which reflects the ratio of the total pigment concentration (sum of AP and chl- $a$ ) to the chl- $a$ concentration, showed a higher correlation with $F_{\mathrm{L}}$ than $a_{\mathrm{ph}}(488) / a_{\mathrm{ph}}(555)$. Thus, we believe that if accurate remote sensing of $a_{\mathrm{ph}}(\lambda)$ in red light, such as $a_{\mathrm{ph}}(667)$, could be achieved with sufficient confidence, the accuracy of $F_{\mathrm{L}}$ estimation will improve. Although several studies have tried to derive $a_{\mathrm{ph}}(\lambda)$ for red light (e.g. Simis et al., 2005; Zhang et al., 2010), their 


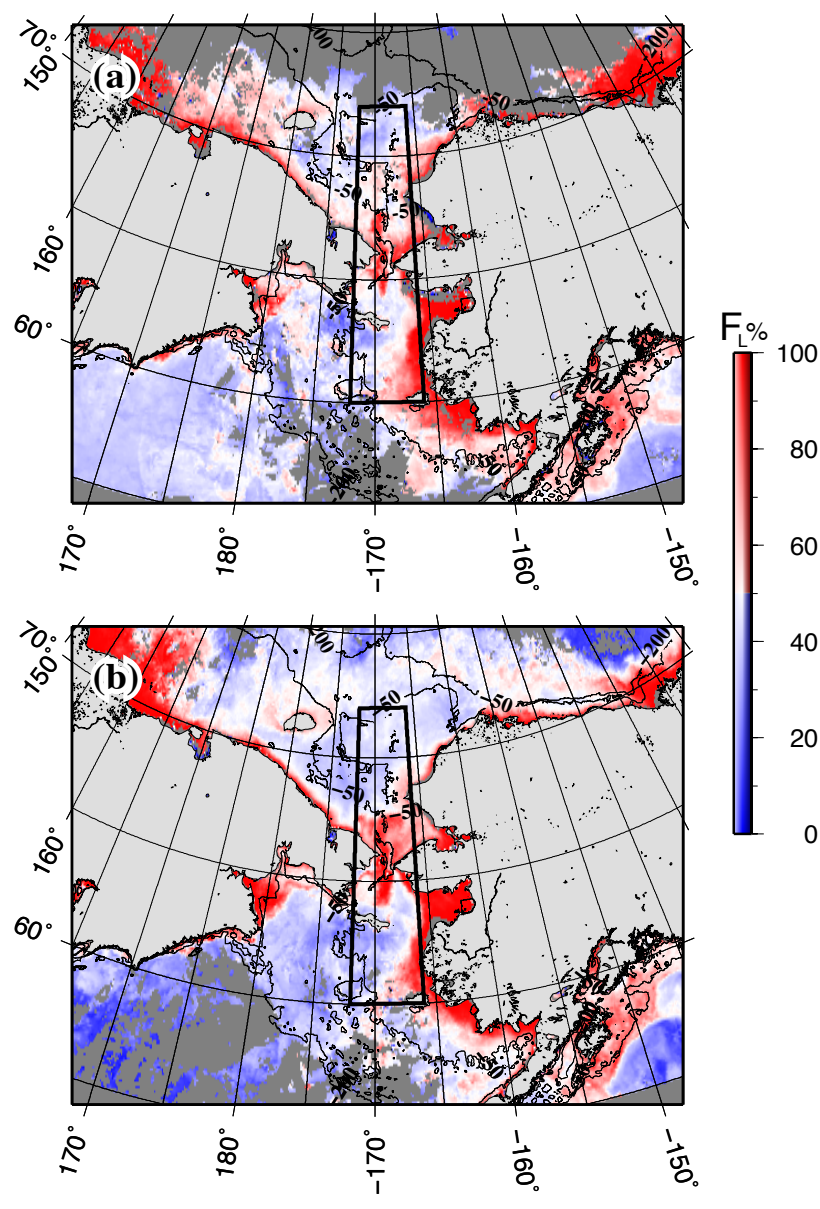

Fig. 4. Satellite-retrieved map of monthly composited $F_{\mathrm{L}}$ in the study region for (a) August 2006 and (b) August 2007. Gray indicates the invalid pixels according to the presence of clouds or sea ice. Frames located at $60-72^{\circ} \mathrm{N}, 166-172^{\circ} \mathrm{W}$ indicate the area for which statistical analysis was performed (Table 5, Fig. 5) for $F_{\mathrm{L}}$, chl- $a$ and SST. Bathymetry contours indicated are 50- and 200-m intervals.

success can be limited to cases of high $a_{\mathrm{ph}}(\lambda)$ in land water. Therefore, $a_{\mathrm{ph}}(488) / a_{\mathrm{ph}}(555)$ was used as an independent variable of the SDM in this study. Additionally, there are several IOP models to derive $a_{\mathrm{ph}}(\lambda)$ and $b_{\mathrm{bp}}(\lambda)$ besides QAA, Garver-Siegel-Maritorena model (GSM, Maritorena et al., 2002), Carader model (Carder et al., 1999) and PML model (Smyth et al., 2006), for instance. Note that some models use fixed shape of $a_{\mathrm{ph}}(\lambda)$ spectra (e.g. GSM and Carder model). Although these IOP models are suitable for global remote sensing and can minimise estimation errors, $a_{\mathrm{ph}}(488) / a_{\mathrm{ph}}(555)$ and $a_{\mathrm{ph}}(443) / a_{\mathrm{ph}}(667)$ will be constant. On the other hand, Smyth et al. (2006) reported larger estimation error in $a_{\mathrm{ph}}(555)$ in spite of thier accurate estimation in shorter wavelength because of exclusion of Raman scattering and its small contribution to $a_{\mathrm{t}}(555)$. Therefore, we conclude that QAA is suitable IOP model to derive spectral $a_{\mathrm{ph}}(\lambda)$ in the SDM.
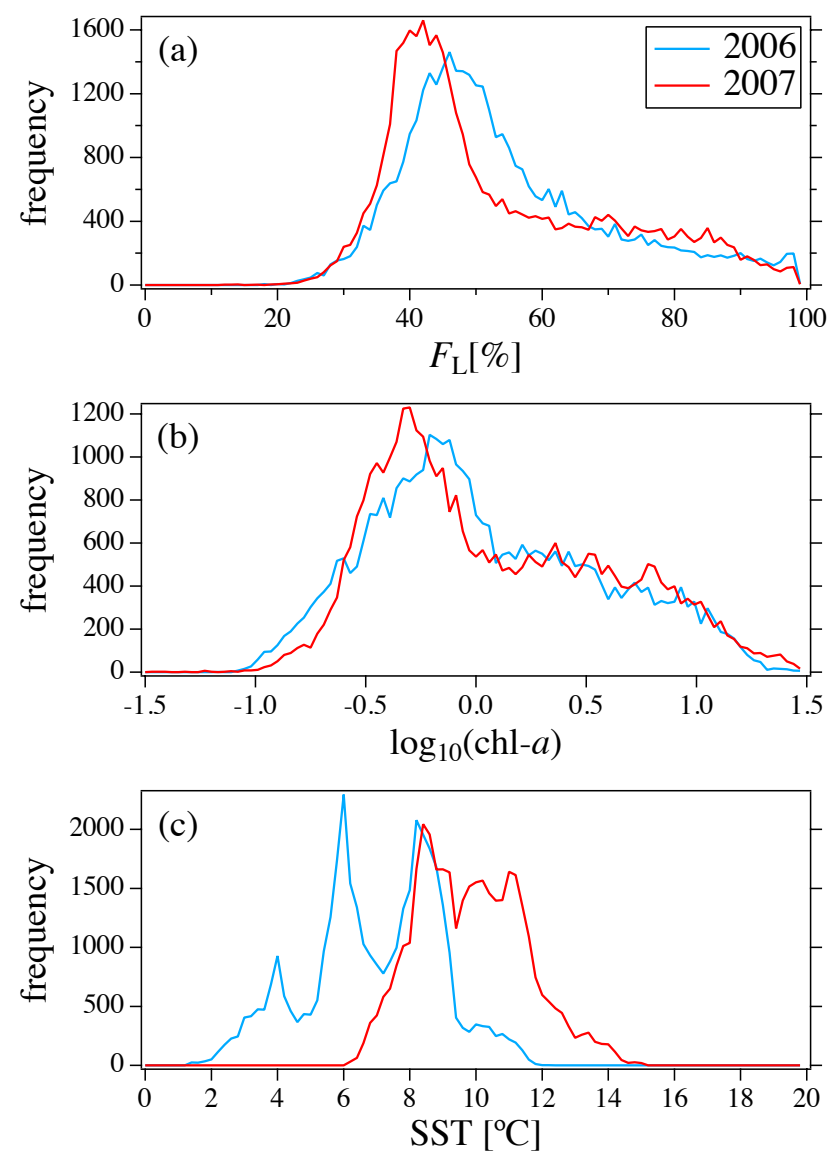

Fig. 5. Histograms of (a) $F_{\mathrm{L}}$, (b) log-transformed chl- $a$ and (c) SST in the area defined in the shelf region (Fig. 4). Blue and red lines indicate the observations of August 2006 and of August 2007, respectively. Valid pixels in the area acount for $91 \%$ of the total pixels for both years. Statistical differences of $F_{\mathrm{L}}$, chl- $a$ and SST are provided in Table 5.

\subsection{Application of SDM to satellite remote sensing}

Figure $4 \mathrm{a}$ and $\mathrm{b}$ show the spatial distribution of $F_{\mathrm{L}}$ in the Western Arctic during August 2006 and August 2007. August is the most stratified season in the Western Arctic. A high proportion of larger phytoplankton assemblages were observed in the continental shelf region around the Bering Strait. In contrast, low $F_{\mathrm{L}}$ was observed in the outer shelf and the Bering basin, which are believed to be nutrient-depleted or iron-limited regions (Aguilar-Islas et al., 2007). Hill et al. (2005) also reported that similar distribution patterns of size-fractionated chl- $a(>5 \mu \mathrm{m})$ in the Chukchi and Eastern Beaufort Sea in summer 2002. In this study, we found different $F_{\mathrm{L}}$ distributions in 2006 and 2007. The distribution of extremely high $F_{\mathrm{L}}(\sim 90 \%)$ had a greater extent in 2007 than in 2006 around the Bering Strait; in contrast, lower $F_{\mathrm{L}}$ values $(\sim 40 \%)$ were distributed more broadly in the northern Chukchi Sea shelf $\left(\sim 67^{\circ} \mathrm{N}\right)$ (Fig. 4a and b). There should be some environmental reasons for the subsequent changes 
Table 5. Statistical difference in monthly averaged $F_{\mathrm{L}}, \log$ transformed chl- $a$ and SST between August 2006 and August 2007. Mean, median, mode and standard deviation values between 2006 and 2007 were provided. All $p$-values applied t-tests and Wilcoxson rank sum tests were less than 0.001 .

\begin{tabular}{lrrrrrr}
\hline & \multicolumn{2}{c}{$F_{\mathrm{L}}$} & \multicolumn{2}{c}{$\log _{10}(\mathrm{chl}-a)$} & \multicolumn{2}{c}{ SST } \\
Year & 2006 & 2007 & 2006 & 2007 & 2006 & 2007 \\
\hline mean & 54.71 & 53.66 & 0.057 & 0.096 & 7.03 & 9.94 \\
median & 50.90 & 47.35 & -0.040 & -0.038 & 7.13 & 9.86 \\
mode & 45.02 & 39.46 & -0.094 & -0.298 & 6.07 & 8.73 \\
SD & 15.53 & 16.82 & 0.264 & 0.280 & 3.98 & 2.67 \\
\hline
\end{tabular}

in the distribution of $F_{\mathrm{L}}$ through the time series. Satellite estimation of $F_{\mathrm{L}}$ can be used for examining how the dominant size of phytoplankton communities in the Western Arctic has responded spatiotemporally to climate change such as the reduction in sea ice. As a preliminary application of the SDM analysis, Fig. 5a-c show frequency histograms of $F_{\mathrm{L}}, \log$-transformed chl- $a$, and SST in the box defined in Fig. $4 \mathrm{a}$ and $\mathrm{b}\left(60-72^{\circ} \mathrm{N}, 166-172^{\circ} \mathrm{W}\right)$ for August 2006 and August 2007. A t-test and a Wilcoxson rank sum test were used to examine the differences in the mean and median values for 2006 and 2007, respectively (Table 5). Although there was a significant decrease $(p$-value $<0.001)$ of $F_{\mathrm{L}}$ in 2007 both in mean and median values (Fig. 5a, Table 5), chl- $a$ showed significant but slight increase ( $p$ value $<0.001$ ) in the both values. In the case of mode values, however, both $F_{\mathrm{L}}$ and chl- $a$ showed remarkable decrease. On the other hand, the SST in 2007 was significantly higher than that in 2006 ( $p$-value $<0.0001$ ) (Fig. 5c, Table 5) and almost all pixel values up to $99 \%$ in the defined box area increased in 2007 (data not shown). Sea ice was distributed in the northern Chukchi Sea around $72^{\circ} \mathrm{N}$ in 2006, but no sea ice cover was found in 2007 (Fig. 4a and b). The Arctic sea ice cover in summer 2007 was the lowest ever observed (http://www.eorc.jaxa.jp/en/imgdata/ topics/2007/tp071024.html). Furthermore, Woodgate et al. (2010) noted that the heat flux into the Arctic Ocean through the Bering Strait in 2007 was greatest during the observation period (1991-2007) and consequently caused the SST increase in 2007. The preliminary result of this study indicates that phytoplankton cell size rather than chl- $a$ can be responsive to ocean warming from 2006 to 2007 in the study region (Fig. 5, Table 5). However, it is not clear whether the shift in the cell size of the algal community observed by the satellite remote sensing is due to the advection of smaller phytoplankton communities from the southern part of the region or to the fact that groups of smaller phytoplankton could be better adapted than groups of larger ones to sudden ocean warming which was showed in incubation experiments (e.g. Noiri et al., 2005 and Hare et al., 2007).
Mean seasonal variability of $F_{\mathrm{L}}$, chl- $a$ and SST in the defined box area are shown in Fig. 6a-c as an additional example of SDM application. $F_{\mathrm{L}}$ and chl- $a$ showed very similar seasonal pattern (Fig. 6a and b) and there is a high correlation between them $(r=0.92) . F_{\mathrm{L}}$ and chl- $a$ showed highest values in the spring and decreased toward the summer along with the SST decrease (Fig. 6a-c). Hill et al. (2005) described that large assemblages released from light limitation increase both their proportion and biomass in the ice-melt season in the Chukchi sea shelf. During the summer, on the contrary, smaller groups increase because of the depletion of nutrients according to the strong stratification. Unfortunately there is little knowledge about autumn phytoplankton species distribution in the region, though SDM could represent seasonal and spatial pattern of phytoplankton size structure consistence with in situ study at least during spring and summer.

Mean inter-annual variability of $F_{\mathrm{L}}, \quad$ chl- $a$, $a_{\mathrm{ph}}(488) / a_{\mathrm{ph}}(555)$ and $\gamma$ in the defined box area are shown in Fig. 7a-d. There is relatively low correlation between inter-annual variability of $F_{\mathrm{L}}$ and chl- $a(r=0.69)$ in August from 2003 to 2010 (Fig. 7a and b) compared to seasonal trend. It is interesting to note that $F_{\mathrm{L}}$ and $a_{\mathrm{ph}}(488) / a_{\mathrm{ph}}(555)$ from 2003 to 2010 exhibit gradual decrease and increase ( $p$-value $<0.05$ ), respectively, though chl- $a$ does not show such significant changes as well as $\gamma$ (Fig. 7a-d). Therefore the different inter-annual trend between $F_{\mathrm{L}}$ and chl- $a$ is comming from derivation of variability of spectral $a_{\mathrm{ph}}(\lambda)$ property. Li et al. (2009) reported that proportion of small phytoplankton assemblage is increasing according to the deepening of nutricline due to recent freshening in the Canada Basin. On the other hand, there have not been reported any evidence of phytoplankton size or community structure change in the shelf region in the past. To our knowledge, this is the first report of the observation of larger phytoplankton decrease in the Bering and Chukchi Sea shelf region. Several studies indicate a significant warming and freshening in the Bering Strait (Woodgate and Aagaard, 2005; Woodgate et al., 2006, 2010; Mizobata et al., 2010). Mizobata et al. (2010) pointed out that increasing in net transport of the Alaskan Coastal Water (ACW) acts an important role in these changes. The ACW is known as a nutrient poor water (Walsh et al., 1989) and distributes at the upper layer due to its lower density. Hence, we suppose that the limitation of nutrient supply from deeper layer is one of the factor to reduce the $F_{\mathrm{L}}$ gradually along with the time series (Fig. 7a)

Distribution of phytoplankton taxa or phytoplankton community size structure depend on sea ice existence (e.g. Gosselin et al., 1997; Hill et al., 2005) and depth of surface mixed layer ( $\mathrm{Li}$ et al., 2009) in the Arctic. Therefore, further analysis with additional data, such as sea ice concentration or salinity distribution, is required to assess the effect of changes in the ocean environment on the structure of phytoplankton assemblages in the study region. However, the SDM established its suitability for monitoring the 

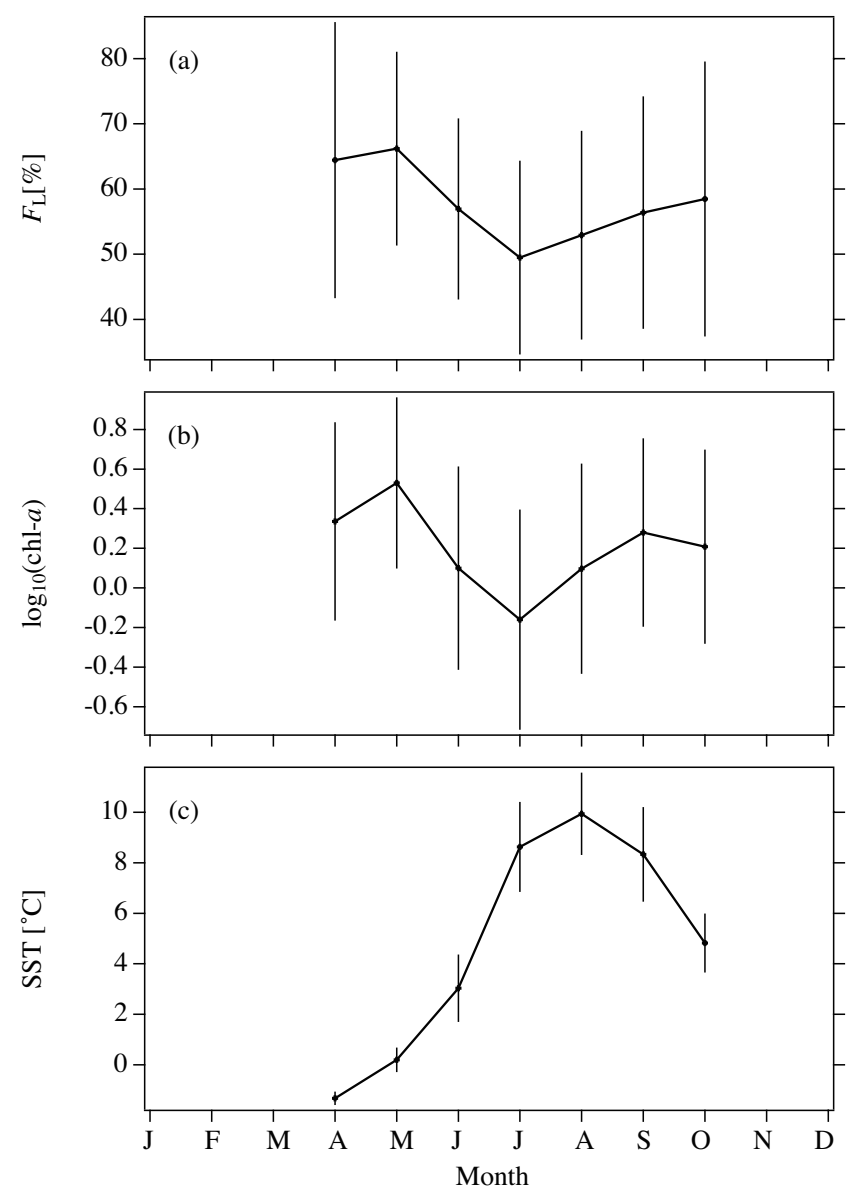

Fig. 6. Seasonal variability of (a) $F_{\mathrm{L}}$, (b) chl- $a$ and (c) SST in the box-averaged area $\left(60-72^{\circ} \mathrm{N}, 166-172^{\circ} \mathrm{W}\right)$ in 2007 . Error bars indicate the standard deviation for each month. Seasonal variablility of $F_{\mathrm{L}}$ and chl- $a$ is highly correlated $(r=0.92, p$-value $<0.001)$. There is no valid data in the area between November and March beacuse of the presence of sea ice and cloud cover.

spatiotemporal distribution of algal size structures by retrieving $F_{\mathrm{L}}$ independent of chl- $a$ (Table 5, Figs. 5a, b, 7a and b). This result demonstrates an advantage of the SDM compared with the chl- $a$-based PFT algorithms proposed in several studies (e.g. Uitz et al., 2006; Brewin et al., 2010; Hirata et al., 2011).

\section{Conclusions}

This study proposes an SDM for deriving phytoplankton cell size structures from space and describes the first experiment that uses multiple optical property inputs; the $a_{\mathrm{ph}}(\lambda)$ ratio indicates the tendency of $F_{\mathrm{L}}$ variation based on physiological optical theory and that of $\gamma$ based on geometrical optical theory. Empirical approaches using either the $a_{\mathrm{ph}}(\lambda)$ ratio or $\gamma$ encounter problems with the estimation of $F_{\mathrm{L}}$; the use of the $a_{\mathrm{ph}}(\lambda)$ ratio causes overestimation when small diatoms $(<5 \mu \mathrm{m})$ dominate and $\gamma$ might be optically influenced by
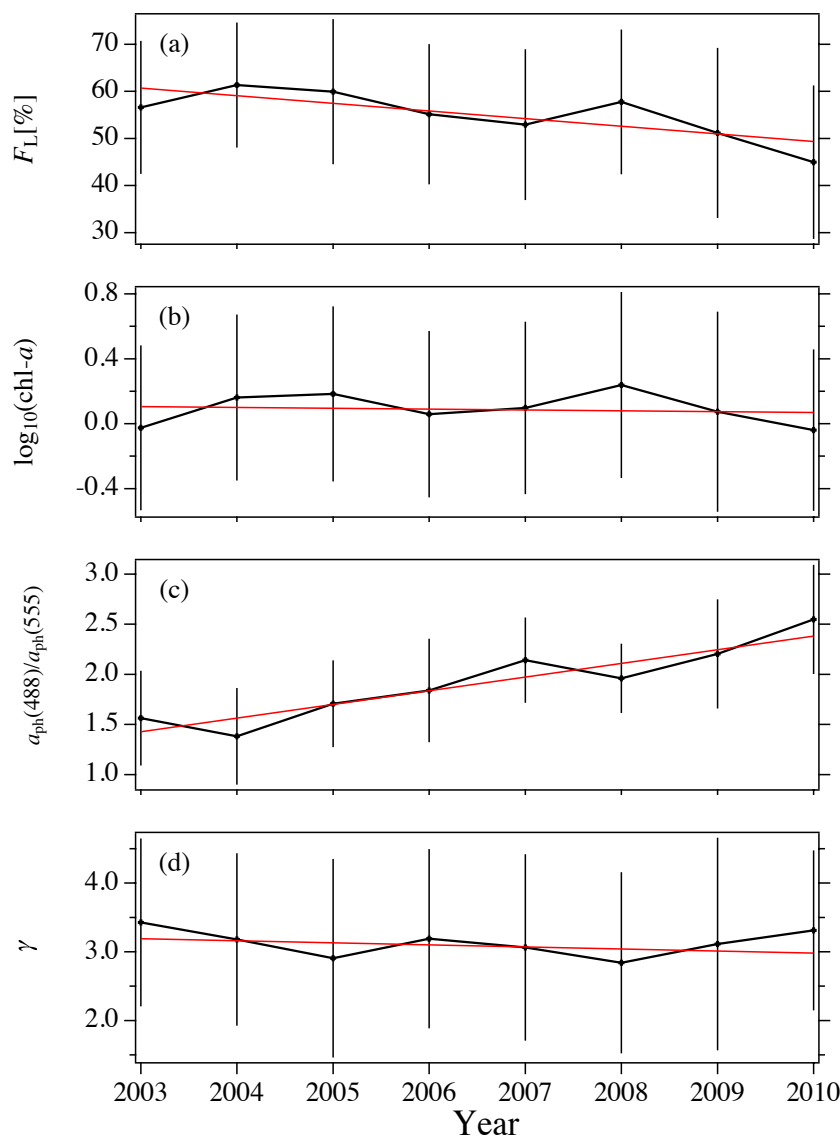

Fig. 7. Inter-annual variability of (a) $F_{\mathrm{L}}$, (b) chl- $a$, (c) $a_{\mathrm{ph}}(488) /$ $a_{\mathrm{ph}}(555)$ and (d) $\gamma$ in the box-averaged area $\left(60-72^{\circ} \mathrm{N}, 166-\right.$ $172^{\circ} \mathrm{W}$ ) of August from 2003 to 2010 . Error bars indicate the standard deviation for each year. Red solid lines indicate regression line for the time series. $F_{\mathrm{L}}$ and $a_{\mathrm{ph}}(488) / a_{\mathrm{ph}}(555)$ show significant decrease $(r=-0.78, p$-value $<0.05)$ and increase $(r=0.93, p$-value $<0.001)$ along with the time series, respectively.

NAPs. To overcome these problems, a multiple logistic regression model that regards the $a_{\mathrm{ph}}(\lambda)$ ratio and $\gamma$ as the independent variables was adopted as the SDM. The advantage of this SDM is that it can retrieve the proportion of $>5 \mu \mathrm{m}$ phytoplankton cells existing in the water, independent of the dominant phytoplankton groups. However, the SDM was developed using only data obtained on a summer cruise of the Oshoro-maru 2007 (OS180). The SDM still needs improvements, such as considerations of seasonal variability of the IOPs and also improved IOP estimation accuracy. However, it performed with sufficient accuracy when applied to unknown data even in high- $a_{\mathrm{CDOM}}(\lambda)$ optically complex water in which the ecosystem's structure has been changing with ocean warming (Grebmeier et al., 2006b). We conclude that application of the SDM to satellite remote sensing has the potential to advance knowledge of the response of phytoplankton to recent climate change and their contribution to the food web in the shelf region in the Chukchi and the Bering Seas. 
Acknowledgements. We sincerely acknowledge the captains and crews of the T/S Oshoro-maru, R/V Mirai, and R/V Hakuho-maru for their cooperation during the cruises. We thank the staffs of JAMSTEC and Marine Work Japan, Ltd., for obtaining and analyzing the data, and A. Tsuda for lending the spectroradiometer. We express our appreciation to the Distributed Active Archive Center (DAAC) at the Goddard Space Flight Center (GSFC) for the production and distribution of satellite data. This study was supported in part by the Japan Society for the Promotion of Science (JSPS) and the IARC/JAXA Information System (IJIS).

Edited by: A. Bricaud

\section{References}

Aguilar-Islas, A., Hurst, M., Buck, K., Sohst, B., Smith, G., Lohan, M., and Bruland, K.: Micro- and macronutrients in the southeastern Bering Sea: Insight into ironreplete and iron-depleted regimes, Prog. Oceanogr., 73, 99-126, doi:10.1016/j.pocean.2006.12.002, 2007.

Aiken, J., Fishwick, J. R., Lavender, S., Barlow, R., Moore, G. F., Sessions, H., Bernard, S., Ras, J., and Hardman-Mountford, N.: Validation of MERIS reflectance and chlorophyll during the BENCAL cruise October 2002: preliminary validation of new demonstration products for phytoplankton functional types and photosynthetic parameters, Int. J. Remote Sens., 28, 497-516, doi:10.1080/01431160600821036, 2007.

Alvain, S., Moulin, C., Dandonneau, Y., and Bréon, F.: Remote sensing of phytoplankton groups in case 1 waters from global SeaWiFS imagery, Deep-Sea Res. Pt. I, 52, 1989-2004, 2005.

Arrigo, K., van Dijken, G., and Pabi, S.: Impact of a shrinking Arctic ice cover on marine primary production, Geophys. Res. Lett., 35, L19603, doi:10.1029/2008GL035028, 2008.

Bidigare, R. R., Ondrusek, M. E., Morrow, J. H., and Kiefer, D. A.: In-vivo absorption properties of algal pigments, in: Proceedings of SPIE, 1302, 290-302, 1990.

Bracher, A., Vountas, M., Dinter, T., Burrows, J. P., Röttgers, R., and Peeken, I.: Quantitative observation of cyanobacteria and diatoms from space using PhytoDOAS on SCIAMACHY data, Biogeosciences, 6, 751-764, doi:10.5194/bg-6-751-2009, 2009.

Brewin, R. J. W., Sathyendranath, S., Hirata, T., Lavender, S. J., Barciela, R. M., and Hardman-Mountford, N. J.: A three-component model of phytoplankton size class for the Atlantic Ocean, Ecol. Model., 221, 1472-1483, doi:10.1016/j.ecolmodel.2010.02.014, 2010.

Bricaud, A. and Morel, A.: Light attenuation and scattering by phytoplanktonic cells: a theoretical modeling, Appl. Optics, 25, 571-580, doi:10.1364/AO.25.000571, 1986.

Carder, K., Chen, F., Lee, Z., Hawes, S., and Kamykowski, D.: Semianalytic Moderate-Resolution Imaging Spectrometer algorithms for chlorophyll a and absorption with bio-optical domains based on nitrate-depletion temperatures, J. Geophys. Res., 104, 5403-5421, 1999.

Chisholm, S. W.: Phytoplankton size, in: Primary Productivity and Biogeochemical Cycles in the Sea, edited by: Falkowski, P. G. and Woodhead, A. D., Plenum Press, New York, 213-238, 1992.

Ciotti, A. and Bricaud, A.: Retrievals of a size parameter for phytoplankton and spectral light absorption by colored detrital matter from water-leaving radiances at SeaWiFS channels in a continen- tal shelf region off Brazil, Limnol. Oceanogr.-Meth., 4, 237-253, 2006.

Ciotti, A., Lewis, M., and Cullen, J.: Assessment of the relationships between dominant cell size in natural phytoplankton communities and the spectral shape of the absorption coefficient, Limnol. Oceanogr., 47, 404-417, 2002.

Cleveland, J. and Weidemann, A.: Quantifying absorption by aquatic particles: A multiple scattering correction for glass-fiber filters, Limnol. Oceanogr., 38, 1321-1327, 1993.

Coachman, L. K., Aagaard, K. and Tripp, R. B.: Bering Strait: The Regional Physical Oceanography, Univ. of Washington Press, Seattle, 172 pp., 1975.

Comiso, J.: A rapidly declining perennial sea ice cover in the Arctic, Geophys. Res. Lett., 29, 17-11, 2002.

Comiso, J. C., Parkinson, C. L., Gersten, R., and Stock, L.: Accelerated decline in the Arctic sea ice cover, Geophys. Res. Lett., 35, L01703, doi:10.1029/2007GL031972, 2008.

Cota, G., Harrison, W., Platt, T., Sathyendranath, S., and Stuart, V.: Bio-optical properties of the Labrador Sea, J. Geophys. Res., 108, 3228, doi:10.1029/2000JC000597, 2003.

Cota, G., Wang, J., and Comiso, J.: Transformation of global satellite chlorophyll retrievals with a regionally tuned algorithm, Remote Sens. Environ., 90, 373-377, 2004.

Darecki, M. and Stramski, D.: An evaluation of MODIS and SeaWiFS bio-optical algorithms in the Baltic Sea, Remote Sens. Environ., 89, 326-350, 2004.

Devred, E., Sathyendranath, S., Stuart, V., and Platt, T.: A three component classification of phytoplankton absorption spectra: Application to ocean-color data, Remote Sens. Environ., 115, 2255-2266, doi:10.1016/j.rse.2011.04.025, 2011.

Feder, H., Jewett, S., and Blanchard, A.: Southeastern Chukchi Sea (Alaska) epibenthos, Polar Biol., 28, 402-421, 2005.

Fishwick, J., Aiken, J., Barlow, R., Sessions, H., Bernard, S., and Ras, J.: Functional relationships and bio-optical properties derived from phytoplankton pigments, optical and photosynthetic parameters; a case study of the Benguela ecosystem, J. Mar. Biol. Assoc. UK, 86, 1267-1280, 2006.

Gosselin, M., Levasseur, M., Wheeler, P., Horner, R. and Booth, B.: New measurements of phytoplankton and ice algal production in the Arctic Ocean, Deep-Sea Res. Pt. II, 44, 1623-1644, 1997.

Grebmeier, J., McRoy, C., and Feder, H.: Pelagic-benthic coupling on the shelf of the northern Bering and Chukchi seas. 1. Food supply source and benthic biomass, Mar. Ecol.-Prog. Ser., 48, 57-67, 1988.

Grebmeier, J., Cooper, L., Feder, H., and Sirenko, B.: Ecosystem dynamics of the Pacific-influenced northern Bering and Chukchi Seas in the Amerasian Arctic, Prog. Oceanogr., 71, 331-361, 2006a.

Grebmeier, J., Overland, J., Moore, S., Farley, E., Carmack, E., Cooper, L., Frey, K., Helle, J., and McLaughlin, F.: A major ecosystem shift in the northern Bering Sea, Science, 311, 14611464, 2006b.

Green, R. E. and Sosik, H. M.: Analysis of apparent optical properties and ocean color models using measurements of seawater constituents in New England continental shelf surface waters, J. Geophys. Res., 109, C03026. doi:10.1029/2003JC001977, 2004.

Hare, C. E., Leblanc, K., DiTullio, G. R., Kudela, R. M., Zhang, Y., Lee, P. A., Riseman, S., and Hutchins, D. A.: Consequences of increased temperature and $\mathrm{CO} 2$ for phytoplankton community 
structure in the Bering Sea, Mar. Ecol.-Prog. Ser., 352, 9-16, doi:10.3354/meps07182, 2007.

Hill, V., Cota, G., and Stockwell, D.: Spring and summer phytoplankton communities in the Chukchi and Eastern Beaufort Seas, Deep-Sea Res. Pt. II, 52, 3369-3385, 2005.

Hirata, T., Hardman-Mountford, N. J., Brewin, R. J. W., Aiken, J., Barlow, R., Suzuki, K., Isada, T., Howell, E., Hashioka, T., Noguchi-Aita, M., and Yamanaka, Y.: Synoptic relationships between surface Chlorophyll- $a$ and diagnostic pigments specific to phytoplankton functional types, Biogeosciences, 8, 311-327, doi:10.5194/bg-8-311-2011, 2011.

Jeffrey, S. W. and Vesk, M.: Introduction to marine phytoplankton and their pigment signatures, in: Phytoplankton Pigments in Oceanography: Guidelines to Modern Methods, edited by: Jeffrey, S. W., Mantoura, R. F. C., and Wright, S. W., UNESCO Publishing, Paris, 37-84, 1997.

Kishino, M., Takahashi, M., Okami, N., and Ichimura, S.: Estimation of the spectral absorption coefficients of phytoplankton in the sea, B. Mar. Sci., 37, 634-642, 1985.

Kostadinov, T., Siegel, D., and Maritorena, S.: Retrieval of the particle size distribution from satellite ocean color observations, J. Geophys. Res., 114, C09015, doi:10.1029/2009JC005303, 2009.

Lalli, C. M. and Parsons, T. R.: Biological Oceanography: An Introduction, Elsevier, New York, 314 pp., 1995.

Lee, Z., Carder, K., and Arnone, R.: Deriving inherent optical properties from water color: a multiband quasi-analytical algorithm for optically deep waters, Appl. Optics, 41, 5755-5772, 2002.

Lee, Z., Lubac, B., Werdell, J., and Arnone, R.: An Update of the Quasi-Analytical Algorithm (QAA_v5), http://www.ioccg.org/ groups/Software_OCA/QAA_v5.pdf, retrieved from http://www. ioccg.org/groups/software.html, 2009.

Li, W. K. W., McLaughlin, F. A., Lovejoy, C., and Carmack, E. C.: Smallest Algae Thrive As the Arctic Ocean Freshens, Science, 326, 539-539, doi:10.1126/science.1179798, 2009.

Lochte, K., Ducklow, H. W., Fasham, M. J. R., and Stienens, C.: Plankton succession and carbon cycling at $47^{\circ} \mathrm{N} 20^{\circ} \mathrm{W}$ during the JGOFS North Atlantic Bloom Experiment, Deep-Sea Res. Pt. II, 40, 91-114, 1993.

Loisel, H., Nicolas, J., Sciandra, A., Stramski, D., and Poteau, A.: Spectral dependency of optical backscattering by marine particles from satellite remote sensing of the global ocean, J. Geophys. Res., 111, C09024, doi:10.1029/2005JC003367, 2006.

Lyon, P. and Hoge, F.: The linear matrix inversion algorithm, in: Remote Sensing of Inherent Optical Properties: Fundamentals, Tests of Algorithms, and Applications, edited by: Lee, Z., Dartmouth, IOCCG, 49-56, 2006.

Maffione, R. and Dana, D.: Instruments and methods for measuring the backward-scattering coefficient of ocean waters, Appl. Optics, 36, 6057-6067, 1997.

Maritorena, S., Siegel, D., and Peterson, A.: Optimization of a semianalytical ocean color model for global-scale applications, Appl. Optics, 41, 2705-2714, 2002.

Mizobata, K., Shimada, K., Woodgate, R., Saitoh, S., and Wang, J.: Estimation of heat flux through the eastern Bering Strait, J. Oceanogr., 66, 405-424, 2010.

Montes-Hugo, M. A., Vernet, M., Smith, R., and Carder, K.: Phytoplankton size-structure on the western shelf of the Antarctic Peninsula: a remote-sensing approach, Int. J. Remote Sens., 29, 801-829, doi:10.1080/01431160701297615, 2008.
Morel, A. and Prieur, L.: Analysis of variations in ocean color, Limnol. Oceanogr., 22, 709-722, 1977.

Mouw, C. B. and Yoder, J. A.: Optical determination of phytoplankton size composition from global SeaWiFS imagery, J. Geophys. Res., 115, C12018, doi:10.1029/2010JC006337, 2010.

Noiri, Y., Kudo, I., Kiyosawa, H., Nishioka, J., and Tsuda, A.: Influence of iron and temperature on growth, nutrient utilization ratios and phytoplankton species composition in the western subarctic Pacific Ocean during the SEEDS experiment, Prog. Oceanogr. 64, 149-166, doi:10.1016/j.pocean.2005.02.006, 2005.

Pabi, S., van Dijken, G., and Arrigo, K.: Primary production in the Arctic Ocean, 1998-2006, J. Geophys. Res., 113, C08005, doi:10.1029/2007JC004578, 2008.

Parkinson, C. and Cavalieri, D.: Arctic sea ice variability and trends, 1979-2006, J. Geophys. Res., 113, C07003, doi:10.1029/2007JC004558, 2008.

Pegau, W. S.: Inherent optical properties of the central Arctic surface waters, J. Geophys. Res., 107, 8035 doi:10.1029/2000JC000382, 2002.

Pegau, S., Ronald, J., Zaneveld, V., Mitchell, B. G., Mueller, J. L., Kahru, M., and Wieland, J.: Ocean optics protocols for satellite ocean color sensor validation, revision 4, in: Inherent Optical Properties: Instruments, Characterizations, Field Measurements and Data Analysis Protocols (Vol. IV), edited by: Mueller, J. L., Fargion, G. S., and McClain, C. R., Goddard Space Flight Cent., Greenbelt, 1-83, 2003.

Reynolds, R., Stramski, D., and Mitchell, B.: A chlorophylldependent semianalytical reflectance model derived from field measurements of absorption and backscattering coefficients within the Southern Ocean, J. Geophys. Res., 106, 7125-7138, 2001.

Sathyendranath, S., Cota, G., Stuart, V., Maass, H., and Platt, T.: Remote sensing of phytoplankton pigments: a comparison of empirical and theoretical approaches, Int. J. Remote Sens., 22, 249-273, 2001.

Sathyendranath, S., Watts, L., Devred, E., Platt, T., Caverhill, C., and Maass, H.: Discrimination of diatoms from other phytoplankton using ocean-colour data, Mar. Ecol.-Prog. Ser., 272, 59-68, 2004.

Shimada, K., Kamoshida, T., Itoh, M., Nishino, S., Carmack, E., McLaughlin, F., Zimmermann, S., and Proshutinsky, A.: Pacific Ocean inflow: Influence on catastrophic reduction of sea ice cover in the Arctic Ocean, Geophys. Res. Lett., 33, L08605, doi:10.1029/2005GL025624, 2006.

Simis, S., Peters, S., and Gons, H.: Remote sensing of the cyanobacterial pigment phycocyanin in turbid inland water, Limnol. Oceanogr., 50, 217-245, 2005.

Smith, R. and Baker, K.: Optical properties of the clearest natural waters (200-800 nm), Appl. Optics, 20, 177-184, 1981.

Smyth, T., Moore, G., Hirata, T., and Aiken, J.: Semianalytical model for the derivation of ocean color inherent optical properties: description, implementation, and performance assessment, Appl. Optics, 45, 8116-8131, 2006.

Springer, A. M. and McRoy, C. P.: The paradox of pelagic food webs in the northern Bering Sea-III. Patterns of primary productivity, Cont. Shelf Res., 13, 575-599, 1993.

Stramski, D., Bricaud, A., and Morel, A.: Modeling the inherent optical properties of the ocean based on the detailed composition of the planktonic community, Appl. Optics, 40, 2929-2945, 
2001.

Sullivan, J. M. and Twardowski, M. S.: Angular shape of the oceanic particulate volume scattering function in the backward direction, Appl. Optics, 48, 6811-6819, 2009.

Suzuki, K., Hinuma, A., Saito, H., Kiyosawa, H., Liu, H., Saino, T., and Tsuda, A.: Responses of phytoplankton and heterotrophic bacteria in the northwest subarctic Pacific to in situ iron fertilization as estimated by HPLC pigment analysis and flow cytometry, Prog. Oceanogr., 64, 167-187, 2005.

Turner, S. M., Malin, G., Liss, P. S., Harbour, D. S., and Holligan, P. M.: The seasonal variation of dimethyl sulfide and dimethylsulfoniopropionate concentrations in nearshore waters, Limnol. Oceanogr., 33, 364-375, 1988.

Uitz, J., Claustre, H., Morel, A., and Hooker, S.: Vertical distribution of phytoplankton communities in open ocean: An assessment based on surface chlorophyll, J. Geophys. Res., 111, C08005, doi:10.1029/2005JC003207, 2006.

Vaillancourt, R. D., Brown, C. W., Guillard, R. R. L., and Balch, W. M.: Light backscattering properties of marine phytoplankton: relationships to cell size, chemical composition and taxonomy, J. Plankton Res., 26, 191-212, doi:10.1093/plankt/fbh012, 2004.

Vidussi, F., Claustre, H., Manca, B., Luchetta, A., and Marty, J.: Phytoplankton pigment distribution in relation to upper thermocline circulation in the eastern Mediterranean Sea during winter, J. Geophys. Res., 106, 19939, doi:10.1029/1999JC000308, 2001.

Walsh, J., McRoy, C., Coachman, L., Goering, J., Nihoul, J., Whitledge, T. E., Blackburn, T., Parker, P., Wirick, C., Shuert, P., Grebmeier, J., Springer, A., Tripp, R., Hansell, D., Djenidi, S., Deleersnijder, E., Henriksen, K., Lund, B., Andersen, P., MüllerKarger, F., and Dean, K.: Carbon and nitrogen cycling within the Bering/Chukchi Seas: source regions for organic matter affecting AOU demands of the Arctic Ocean, Prog. Oceanogr., 22, 277-359, doi:10.1016/0079-6611(89)90006-2, 1989.

Wang, J. and Cota, G.: Remote-sensing reflectance in the Beaufort and Chukchi seas: observations and models, Appl. Optics, 42, 2754-2765, 2003.
Wang, J., Cota, G., and Ruble, D.: Absorption and backscattering in the Beaufort and Chukchi Seas, J. Geophys. Res., 110, C04014, doi:10.1029/2002JC001653, 2005.

Welschmeyer, N.: Fluorometric analysis of chlorophyll a in the presence of chlorophyll $\mathrm{b}$ and pheopigments, Limnol. Oceanogr., 39, 1985-1992, 1994.

Woodgate, R. A. and Aagaard, K.: Revising the Bering Strait freshwater flux into the Arctic Ocean, Geophys. Res. Lett., 32, L02602, doi:10.1029/2004GL021747, 2005.

Woodgate, R. A., Aagaard, K., and Weingartner, T. J.: Interannual changes in the Bering Strait fluxes of volume, heat and freshwater between 1991 and 2004, Geophys. Res. Lett., 33, 15609, doi:10.1029/2006GL026931, 2006.

Woodgate, R. A., Weingartner, T., and Lindsay, R.: The 2007 Bering Strait oceanic heat flux and anomalous Arctic sea-ice retreat, Geophys. Res. Lett., 37, 01602, doi:10.1029/2009GL041621, 2010.

Wozniak, S. and Stramski, D.: Modeling the optical properties of mineral particles suspended in seawater and their influence on ocean reflectance and chlorophyll estimation from remote sensing algorithms, Appl. Optics, 43, 3489-3503, doi:10.1364/AO.43.003489, 2004.

Wright, S. W. and Jeffrey, S. W.: Pigment markers for phytoplankton production, in: Marine Organic Matter: Biomarkers, Isotopes and DNA, edited by: Volkmann, J. K., Springer-Verlag, Berlin, 71-104, 2006.

Yoder, J. A. and Kennelly, M. A.: What have we learned about Ocean Variability from satellite ocean color images?, 119, 152172, 2006.

Zehr, J. and Carpenter, E.: New perspectives on nitrogen-fixing microorganisms in tropical and subtropical oceans, Trends Microbiol., 8, 68-73, 2000.

Zhang, Y., Feng, L., Li, J., Luo, L., Yin, Y., Liu, M., and Li, Y.: Seasonal-spatial variation and remote sensing of phytoplankton absorption in Lake Taihu, a large eutrophic and shallow lake in China, J. Plankton Res., 32, 1023-1037, doi:10.1093/plankt/fbq039, 2010. 